\title{
Remembering Burke Marshall
}

\author{
Hillary Rodham Clinton ${ }^{\dagger}$
}

I am deeply honored and delighted to have been asked to be part of this remembrance and celebration of an extraordinary American, a great lawyer, a caring and thoughtful professor, and a friend over so many years. To Violet, Josie, Catie, Jane, and other members of the Marshall family, you know the depth of the personal loss that this represents to you. To many of us, it was also personal, and it was in the very best sense of the word political and public as well.

I was fortunate enough to be a student at the Law School when Burke Marshall came back to teach in 1970 . He came with his reputation and legendary commitment to civil rights surrounding him. I didn't know what Burke Marshall looked like. I had read about this giant among men who stood down the worst of the segregationists, who was always there willing to shepherd civil rights demonstrators through crowds of angry and swearing people. So I was looking way up toward the ceiling, expecting this giant among men to stride down the hallway, when someone sort of poked me and said, "There, that's Burke Marshall." Bespectacled, stooped, deferential. I immediately was even more drawn to him because of the contrast with all the stories that I and so many law students and people who cared deeply about the civil rights revolution transforming our country had heard. It was even more amazing to envision him doing all of these wondrous, courageous feats.

In 1973, my husband and I were in charge of the Barristers' Union trial for that year, and the guest judge was someone whom Burke invited-John Doar. John, Burke, Bill, and I had a wonderful conversation about our postgraduation plans. I, of course, had very little idea of what I was going to do. Bill intended to go back to Arkansas to pursue a yet-undefined political and public life, but needed a job. In the course of the conversation, Burke asked Bill if he'd ever thought about teaching and Bill said, "Well,

$\dagger$ United States Senator from New York. This Tribute is an edited version of oral remarks given at a memorial service for Burke Marshall at the New Haven Lawn Club on September 21, 2003. 
no, I hadn't. Do you think that would be a good decision?" Burke said, "Sure. I'll even write a letter of recommendation." So he wrote a letter, which to my memory went something like, "Dear Dean of the Arkansas Law School, I recommend this young man who is quite intelligent and could be a good law professor, but will probably not stay long. However, if I were you, I'd still give him a job." I had my own conversation with Burke because I was trying to decide whether to go to Arkansas, a place I had never lived and knew no one but Bill, or go to work for Marian Wright Edelman at the newly created Children's Defense Fund. Burke was not one to give people advice about their personal lives, but he said, "Well, you know, I know Marian, and I think it would be a wonderful job. It would be very educational." I took that as some kind of sign of approval and went off to Cambridge.

In late 1973 or early 1974, John Doar, whom we had met at Yale thanks to Burke's invitation, called Bill and called me and asked us to come to work for him on the impeachment inquiry staff of the House Judiciary Committee investigating President Nixon. That is, as you may recall, what I refer to as the constitutional impeachment of the twentieth century. Burke had advised John about five graduating lawyers whom he highly recommended John hire. Bill was one, I was one, and there were three other of my classmates. John called Bill first and invited Bill to join, and Bill said, "You know, I think I've decided to run for Congress." As I again recall, hearsay of course, John said, "You know, Burke told me you might not be a law professor for very long. But I've got some other names on the list. What do you think of these?" He read off the other names, including mine, and Bill said, "Oh, they're wonderful choices." So John called me, I accepted, and went to work for him. From time to time during those intense months leading up to the presentation of the articles of impeachment to the Judiciary Committee, we would have the benefit of a visit from Burke. He would come into the old congressional hotel where we were headquartered and go from office to office visiting with people, kneading over all of the difficult problems that we were confronting. He was of great support to all of us in a very difficult time.

If I fast-forward in remembrances, I think of a conversation that I had with Jacqueline Kennedy Onassis in June of 1992. Jackie had been one of Bill's earliest supporters, which came as something of a surprise to us: As early as the summer of 1991, she sent word that if Bill decided to run, she wanted to support him. Then when he did decide to run in October of 1991, Jackie and her son John were among two of the earliest contributors to the Clinton for President campaign. We never knew quite how that came about. In June of 1992, after Bill had secured the nomination, I went for lunch at Jackie's apartment in New York City and while we were sitting having lunch I inquired, "It was such a wonderful surprise when we got word that 
you wanted to support Bill even before he reached $0.1 \%$ in national polls. How did that come about?" She said, "Well, Burke Marshall told me that if Bill Clinton decided to run for president, I should back him, I would like him, I would agree with him, and he would win." So his acumen in dissecting presidential politics is much to be respected and remembered.

My final remembrance is vintage Burke as well. In the fall of 1998, when you may recall there was another impeachment brewing, I received a phone call in the White House from Burke. I hadn't talked to him in quite some time. I was always passing greetings to him through someone else; he was passing greetings to me; we saw one another when I came to Yale for class reunions, but we certainly had not had a lengthy or personal conversation in many, many years. I picked up the phone and he said to me, "You've got to stop this impeachment." I said, "Well, I couldn't agree more. But I have no idea how to go about doing that." He then proceeded to give me eloquent, forceful, heartfelt reasons why this was a terrible thing for our country and to talk with me for a few minutes about what, if anything, I could think of that he or others could do that might make a difference. I told him that I was sure that there were many ways in which distinguished law professors and others could speak out about what I considered to be the unconstitutionality of this particular proceeding and that such steps would be very welcome. He said, "You know, that's just not good enough. I think this is a serious threat to the presidency, and the presidency must be preserved. You should just tell Bill not to cooperate under any circumstances." I said, "Gosh, Burke, I don't know about that." He replied, "It is such a serious threat that I know that there's a way out of it. He should not in any way, in any way, participate in this terrible process." I agreed with Burke one hundred percent but, as I told him, I just couldn't see any way that could come about, although certainly any outpouring of academic and lawyerly criticism of this out-of-control process would be most welcome.

When I think of Burke Marshall, I think of someone who really represents the very best that America has to offer in its continuing and unfinished business of justice and equality. There isn't any doubt that we are a better country because of Burke Marshall. There isn't any doubt that he remains a hero for anyone who understands how difficult America's journey in dealing with race has been and continues to be. I hope that as we honor him, as we think of the legacy that he leaves, as we remember the incredible courage that he showed on behalf of his ideals and his rockbottom belief in the American capacity for justice, that we will inspire others to follow in those footsteps. I am struck by how difficult it seems to be these days for people to stand up and speak out, to take on the forces of reaction and radicalism, to understand so clearly that many of the same 
voices that we hear today who wish to turn the clock back were the ones who opposed the important laws Burke Marshall championed.

I am reminded of a quote from one of our mutual friends, Congressman John Lewis, who goes to work every day knowing that he is facing some stiff odds and still tries with all his heart to make it possible for us to have what he calls a "beloved community" in our country. In these pages in 1995, he said, "In times of great struggle and conflict in the South-during the freedom rides of 1961, when young people were being beaten by angry mobs in Montgomery, and when fire hoses and dogs were being turned on people in Birmingham-people always said, 'Call Burke.",l

Our nation owes an enormous debt of gratitude to this quiet, independent, courageous, fiercely intelligent man, not only for helping to craft the Civil Rights Act of 1964 and for doing the work that led to the Voting Rights Act of 1965, and not only for the role that he played as persuader and peacemaker during those difficult and turbulent times. But I hope that we also think of what he might say to us in the times we face today and in the future that lies ahead. We can't call Burke anymore, but we can certainly call to mind his example, and if we do that I think we can, in our own ways, continue his work. 